\title{
Kolesterol gjennom mer enn 25 år: Kan svarene sammenliknes over så lang tid?
}

\author{
Olav Per Foss og Petter Urdal \\ Klinisk kjemisk avdeling, Ullevål universitetssykehus, 0407 Oslo
}

\begin{abstract}
ENGLISH SUMMARY
Determination of serum totalcholesterol was part of the longitudinal health screening programme carried out in the majority of counties in Norway 1974-2001. The analytical method for cholesterol determination was subjected to an excessive internal and external quality control. Commercial quality control sera with given cholesterol values were analysed several times every day. Samples received from WHO Regional Lipid Reference Centre in Prague were analysed frequently. Samples received from the Lipid Research Clinic, George Washington University, USA, from the National Bureau of Standards, USA, and from the Danish laboratory using "high performance methods" were also analysed. Further the laboratory participated in the Norwegian laboratory control system. It was unveiled that the analytical level dropped by 8 per cent in 1979 when the enzymatic method replaced the non-enzymatic method. The results obtained by the enzymatic method were in better agreement with those found with high performance methods than those found with the non-enzymatic method. The results obtained before the shift of method were recalculated in order to bring them in accordance with those after the shift. Shift in instrument in 1997 could have caused an increase in the analytical level by 2 per cent. The instrument was therefore adjusted to keep the analytical level constant. Thus the control system documents that the analytical level in the determination of totalcholesterol - after adjustements - has been constant during the period 1974-2002. The observed drop in mean totalcholesterol among Norwegians during this period is real and not caused by analytical unstability.
\end{abstract}

\section{INNLEDNING}

Statens helseundersøkelser (SHUS), senere Nasjonalt folkehelseinstitutt, har helt siden 1974 vært involvert i regionale helseundersøkelser for hjerte-karsykdom, først i pilotfylkene Finnmark, Sogn og Fjordane og Oppland $(1,2)$ og fra 1985 i de fleste andre fylker. Undersøkelsen har vært regelmessig gjentatt $i$ de respektive fylker, og dette har gjort at man har kunnet følge utviklingen i risikofaktorer for hjerte-karsykdom over tid (3).

I langtidsstudier ligger det en spesiell utfordring $\mathrm{i}$ å sikre at data innsamlet $\mathrm{i}$ forskjellige tidsperioder er sammenliknbare. Dette forutsetter at dataene samles inn på en nøye standardisert og dokumenterbar måte som sikrer at de kan sammenliknes over tid og ved endring av etablerte prosedyrer. I SHUS sine studier har kardiovaskulær risiko vært beregnet ut fra kjønn, røkevaner og forekomst av koronar sykdom i den nære familie samt målt blodtrykk og kolesterol. Vi skal her se nærmere på de målemetoder og kontrollrutiner som har vært fulgt for å sikre at kolesterol-svarene er sammenliknbare over disse godt 25 år.

\section{MATERIALER OG METODER}

Samlet har mer enn 800.000 personer vært undersøkt i tidsrommet 1974-2002. Fra alle deltakere ble det tatt en ikke-fastende blodprøve til måling av kolesterol og triglycerider. HDL kolesterol ble målt i samme prøve fra 1980 mens glukose har vært målt i perioder. Alle målingene ble utført ved Klinisk kjemisk avdeling, Ullevål universitetssykehus (4).

\section{Målemetoder og måleutstyr}

Målemetode og/eller måleutstyr har vært byttet når dette ble vurdert nødvendig ut fra faglige og praktiske forhold. Tabell 1 summerer opp de målemetoder og måleutstyr som har vært nyttet.

Den første metoden, Liebermann-Burchards, var ikke-enzymatisk og ble kalibrert med rent, innveiet kolesterol løst $\mathrm{i}$ isopropanol. Ved de senere metodene, som alle var enzymatiske, kunne vi ikke nytte en slik ren standard og måtte isteden nytte en kommersielt tilgjengelig kalibrator basert på serum og med kolesterol målt med en referansepreget metode. Dens verdi var sporbar til et referanseserum og en referansemetode, hvilket sikret en mest mulig korrekt verdi. Kalibrering ble utført dersom man endret målemetode eller måleutstyr eller dersom analysen av kontroller tydet på at analysen lå på feil nivå.

\section{Kontrollsystemer}

Kontrollsystemer er viktige for å minimalisere nivåendringer over tid og for å dokumentere grad av nivåendring mellom og ved bytte av målemetode. Samlet gir kontrollsystemene også mulighet for å vurdere kvaliteten på analysen over tid. De kontrollsystemene som ble benyttet er oppsummert i Tabell 2 . 
Tabell 1. Målemetoder og målesystemer for kolesterol i serum for Statens helseundersøkelser 1974-2002.

\begin{tabular}{llll}
\hline Tidsrom & Målemetode & Reagens fra & Måleutstyr \\
\hline 1972-1979 & $\begin{array}{l}\text { Liebermann- } \\
\text { Burchard }\end{array}$ & Egenlagede & Technicon Autoanalyzer \\
1979-1986 & Enzymatisk & Roche & Technicon Autoanalyzer \\
$1986-1997$ & Enzymatisk & Roche & Hitachi 737 \\
$1997-2000$ & Enzymatisk & Roche & Hitachi 911 \\
2000-2002 & Enzymatisk & Roche & Hiatchi 917 \\
\hline
\end{tabular}

Tabell 2. Kvalitetskontrollsystemer for kolesterol i serum for Statens helseundersøkelser 1974-2002.

\begin{tabular}{l}
\hline Ekstern kvalitetskontroll \\
Sammenlikning mot referansemetode \\
Sammenlikning mot andre bruksmetoder \\
\hline Intern kvalitetskontroll \\
Gjentatt analysering av kontrollsera med kjent kolesterolverdi \\
Forskjellige kontrollsera på forskjellig nivå \\
• Vurdering av daglige enkeltverdier \\
• Beregning av månedlig middelverdi \\
\hline Bytte av målemetode eller utstyr \\
Mange pasientprøver analysert med begge metoder \\
Gjentatt analysering av kontrollsera \\
\hline
\end{tabular}

Ekstern kvalitetskontroll består i at man i samarbeid med et referanselaboratorium eller andre rutinelaboratorier analyserer en eller flere felles pasientprøver og sammenlikner de oppnådde svar. Derved får man mulighet til å vurdere kvaliteten på egen analyse, at denne ligger på et riktig nivå. Hva angår sammenlikning mot referanselaboratorium ble det i perioden 1973-1980 mottatt og analysert to ganger årlig prøver fra WHO sitt Regional Lipid Reference Center i Prag og i 1976 analysert prøver fra Lipid Research Clinic, George Washington University, USA. I 1988 mottok og analyserte laboratoriet standard reference sera fra National Bureau of Standards (NBS), USA, og danske referansesera hvor kolesterol var bestemt med "high performance methods". I 1992 og 1993 ble det sendt prøver til laboratorier i USA tilknyttet "Cholesterol reference method laboratory network". Hva angår sammenlikning mot andre rutinelaboratorier har denne hele tiden vært organisert gjennom Norsk Klinisk Kjemisk Kvalitetskontroll, en ideell stiftelse organisert av de norske laboratorier som har sendt ut 1-2 prøver pr. måned og sammenliknet de innkomne enkeltsvar mot middelverdien av alle svar og av og til mot et svar oppnådd ved et referanselaboratorium.

Intern kvalitetskontroll hvor man flere ganger pr. dag analyserer ett eller flere kontrollsera med kjent kolesterol-konsentrasjon, gir grunnlag for å kunne gi ut pasientsvar. Kontrollseraene hadde 2-4 års holdbarhet og ble derfor også nyttet til å vurdere om nivået på analysen var stabilt i denne tidsperioden.
Ved bytte av målemetode og/eller måleutstyr er det viktig å sikre at den nye metoden er tilstrekkelig god, at det skjer en minst mulig endring i nivå ved byttet samt å dokumentere grad av nivåendring og kvaliteten på den nye målemetoden. Dette ble gjort ved at man gjennom flere måneder og med både gammel og ny metode analyserte 200-300 prøver med kolesterol i hele spekteret fra lave, middels og høye verdier. I tillegg ble det regelmessig og med begge metoder i samme tidsperiode analysert kontrollprøver på forskjellig nivå.

\section{ReSUlTATER}

Den første målemetoden, Liebermann-Burchards metode, ble også brukt ved de store befolkningsundersøkelsene i USA (1) og var en rent kjemisk metode som benyttet etsende reagenser. Metoden var ikke helt spesifikk for kolesterol idet den også i noen grad medmålte andre lipider. De senere metoder benyttet alle kolesterol-spesifikke enzymer som reagens.

Den ikke-enzymatiske målemetoden var forholdsvis ustabil og krevet daglig kalibrering, mens de enzymatiske metoder var og er meget stabile og trengte sjelden å bli kalibrert. Således ble den enzymatiske metoden som ble brukt på Hitachi 737 kalibrert ved oppstart i 1986 men siden ikke rekalibrert i løpet av de 11 år systemet var i bruk.

Målemetoden ble nivåsatt med en kalibrator hvor kolesterol var bestemt med en høykvalitets referansemetode. Nivåsettingen på analysen ble de første år vurdert ved gjentatte sammenlikninger mot WHO sitt referanselaboratorium. Sammenlikningen viste at Liebermann-Burchards metode i gjennomsnitt ga ca. $0,4 \mathrm{mmol} / \mathrm{l}$ høyere verdier enn det referansemetoden ga. Ved overgang til enzymatisk målemetode i 1979 sank nivået på analysen med $8 \%$, hvilket svarer til 0,4 $\mathrm{mmol} / 1$ på nivå $5 \mathrm{mmol} / \mathrm{l}$. Den eksakte korrelasjonslikningen var: Ny metode $(\mathrm{mmol} / \mathrm{l})=0,92 \cdot$ gammel metode $(\mathrm{mmol} / \mathrm{l})+0,03$. Ved analyse i 1988 av kontrollsera fra NBS, USA og fra Danmark var det full overensstemmelse mellom de oppgitte verdier og våre målte verdier. Ved sammenlikning i 1992 og 1993 mot laboratorier tilknyttet det amerikanske "Cholesterol reference method laboratory network" var vårt avvik begge ganger på under $1 \%$. Månedlig sammenlikning mot andre norske laboratorier, gjennom Norsk Kvalitetskontroll, har heller ikke vist langvarige systematiske avvik i nivå.

Forut for hvert bytte av målemetode og/eller måleutstyr ble det utført en sammenlikning av gammel og ny metode. Bare i 1979 medførte metodeendringen at nivået på analysen endret seg, som angitt over. Ved byttet i 1997 ble den nye metoden korrigert ned med $2 \%$ for å unngå endret nivå, ellers har korreksjon ikke vært nødvendig etter 1979.

Intern kvalitetskontroll med beregning av månedlig eller kvartalsvis middelverdi ga mulighet for påvisning av selv små endringer $\mathrm{i}$ nivå på analysen, som vist $\mathrm{i}$ 
Figur 1. Et skifte av reagens i november 1990 medførte et fall på 2\%, hvilket ble påvist og korrigert i mars 1991. Forøvrig ble ikke påvist lengrevarig systematisk avvik i nivå, typisk avvek den månedlige middelverdi for en kontroll med mindre enn $1 \%$ fra sin målverdi.

\section{DISKUSJON}

Et ideelt utgangspunkt for en langtidsstudie kunne kanskje være at man ikke skiftet hverken metoder eller utstyr. Da ville man unektelig fått sammenliknbare resultater over tid. Et slikt standpunkt lar seg imidlertid ikke forsvare når det gjelder måling av kolesterol, hvilket skyldes at de tilgjengelige metoder har bedret seg betydelig over tid. Metodene har blitt mer spesifikke og presise og blitt lettere å holde stabile over tid. Dersom man hadde beholdt de gamle metoder, ville resultatene etter hvert ha blitt vurdert som upålitelige og lite brukbare for sammenlikning med tidligere funn og mot andre undersøkelser.

Helseundersøkelsene har vært krevende fordi de har gått over lang tid og selv små endringer i nivå ville kunne være av klinisk betydning. For å unngå slike endringer i analysens nivå var det viktig å etablere gode målemetoder og gode kontrollrutiner av disse, et behov vi delte med andre store, langsgående helseundersøkelser (5-8). I dette arbeidet har intern og ekstern kvalitetskontroll vært viktig (4). Den interne kvalitetskontroll har primært sikret at analysens nivå ikke har endret seg over tid. Kontrollsera brukt til dette formål har vært stabile i flere år og har gjort at selv mindre endringer i nivå kunne la seg påvise og korrigere, som vi også har gjort. Ekstern kvalitetskontroll muliggjør objektiv vurdering av nivåsetting på analysen. Derved kunne vi dokumentere at den ikke-enzymatiske metode ga for høye verdier mens enzymatiske metoder har gitt nær korrekte verdier. Korrelasjon mellom gamle og nye verdier gjorde at alle kolesterol-svar oppnådd før 1979 kunne omgjøres, i henhold til korrelasjonslikningen gitt i resultatavsnittet, og derved bli sammenliknbare med senere oppnådde verdier.

Samlet har kontrollsystemene dokumentert at analytisk nivå har forandret seg lite når unntas nivåendringen i 1979. Samtidig har den midlere kolesterolkonsentrasjon i den norske befolkning i løpet av disse mer enn 25 år falt med 0,6-0,8 mmol/1, som vist i Figur 2. Dokumentasjonen av en stabil analyse gir grunnlag for å tro at dette var en reell endring i befolkningen.

Hypotetisk kunne man tenke seg at endringene vist i Figur 2 kunne skyldes endring i populasjonen som deltar i undersøkelsen eller endring i prøvetakingen. Endret populasjon synes urimelig siden man har innkalt hele aldersgrupper og en stor andel av disse har møtt. Fallende kolesterol kunne i prinsippet skyldes at en større del av de undersøkte fikk tatt sin blodprøve fastende, men heller ikke dette synes rimelig siden antall timer siden siste måltid blir registrert og dette timetallet har ikke endret seg markant i løpet av disse årene. Av disse grunner må man kunne konkludere med at det har vært et reelt og betydningsfullt fall $i$ serumkolesterol-konsentrasjon i den norske befolkning. Det er naturlig å knytte fallet $\mathrm{i}$ hyppighet av kardiovaskulær sykdom i disse årene til fallet i kolesterol-konsentrasjon. Disse funn samsvarer da også godt med liknende funn gjort i andre land $(5,7)$.

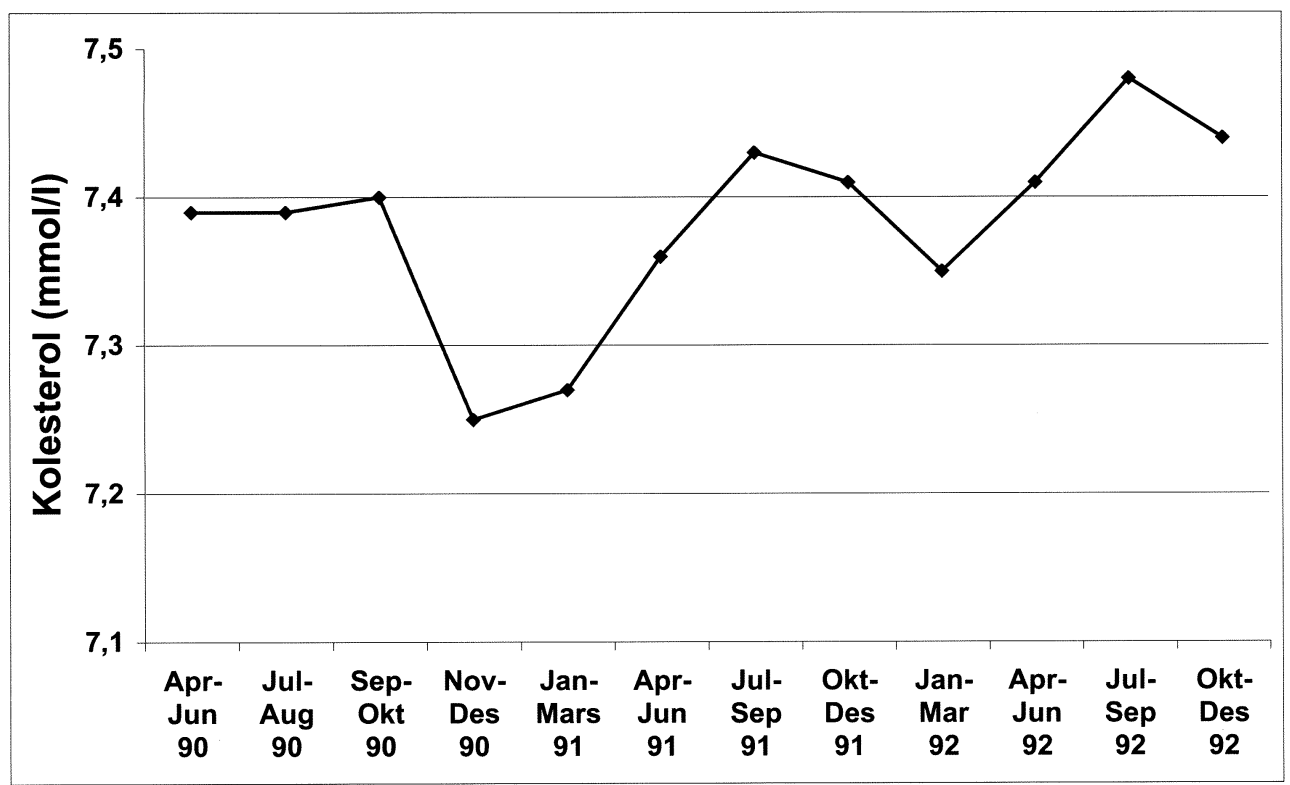

Figur 1. Kvartalsvis gjennomsnitt i kolesterol-konsentrasjon for kontrollserum benyttet som kontroll for prøver fra SHUS. Målverdi for kontrollen var $7.41 \mathrm{mmol} / 1$. 


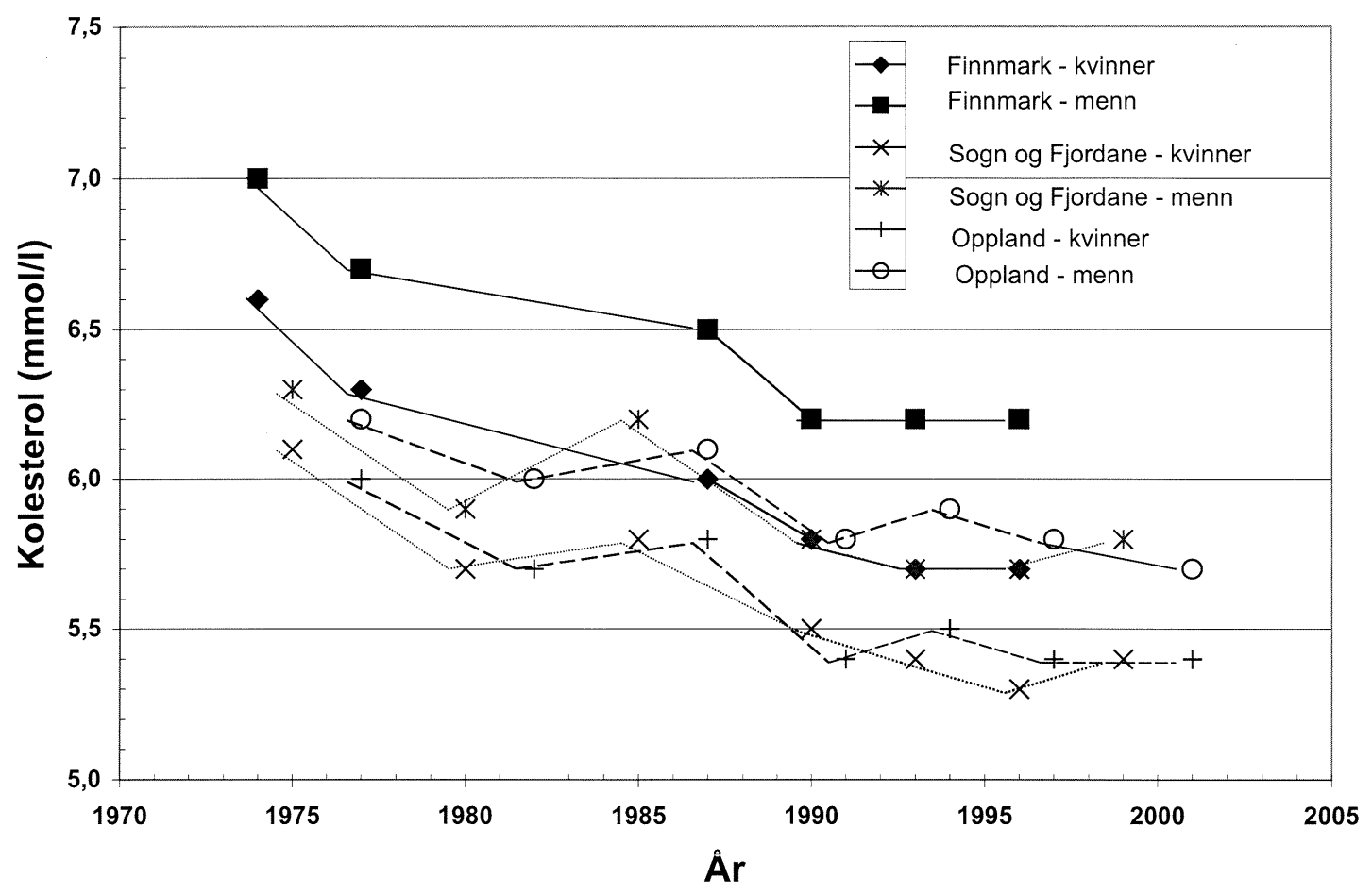

Figur 2. Gjennomsnitts kolesterolkonsentrasjon i serum hos menn og kvinner alder 40-42 år i Sogn og Fjordane, Finnmark og Oppland i tidsperioden 1974-2002

\section{REFERANSER}

1. Bjartveit K, Foss OP, Gjervig T, Lund-Larsen PG. The cardiovascular disease study in Norwegian counties background and organization. Acta Med Scand 1979; suppl 634: 1-70.

2. Bjartveit K, Foss OP, Gjervig T. The cardiovascular disease study in Norwegian counties - results from the first screening. Acta Med Scand 1983; suppl 675: 1-184.

3. Tretli S, Bjartveit K, Foss OP, Haider T, Lund-Larsen PG. Intervention on cardiovascular disease risk factors in Finnmark county. Changes after a period of three years. Scand J Soc Med 1985: 13: 1-13.

4. Foss OP. Lipid analyses at Central Laboratory Ullevål Hospital 1972-1989. Accuracy - presicision - stability. Oslo: Ullevål sykehus, Sentrallaboratoriet 1989.

5. Sytkowski PA, Kannel WB, D'Agostino RB. Changes in risk factors and the decline in mortality from cardiovascular disease. The Framingham Heart Study. N Engl J Med 1990; 323: 1704-6.

6. Cull CA, Manley SE, Stratton IM, Neil HAW, Ross IS, Holman RR, Turner RC, Matthews DR. Approach to maintaining biochemical data during long-term clinical trials. Clin Chem 1997; 43: 1913-8.

7. Szklo M, Chambless LE, Folsom AR, Gotto A Jr, Nieto FJ, Patsch W, Shimakawa T, Sorlie P, Wijnberg L. Trends in plasma cholesterol levels in the atherosclerosis risk in communities (ARIC) study. Prev Med 2000; 30: $252-9$.

8. Critchley JA, Capewell S. Prospective cohort studies of coronary heart disease in the UK: systematic review of past, present and planned studies. J Cardiovasc Risk 2003; 10: 111-9. 